\title{
Resenha
}

\section{Excluindo sem saber}

\section{Excluding without knowing}

Rosimeire Maria Orlando Zeppone*

MARIN, A. J.; BUENO, J. G. S. (Orgs.). Excluindo sem saber. Araraquara, SP: Junqueira\&Marin; Brasília, DF:CNPQ, 2010.

Que as discussões acerca da inclusão escolar na escola pública brasileira merecem destaque e têm ganho maior importância, é fato que não se pode negar. Com uma abordagem sociológica e tendo como principal referência Pierre Bourdieu, os autores desse livro, preocupados com a situação da escola atual, e citando o termo cunhado por Ferraro (1999) "exclusão na escola", para se referir ao alunado que permanece na escola, mas com defasagem idade/ série ou os índices baixos de rendimento escolar, apontados nas avaliações tanto nacionais quanto internacionais, problematizam as formas de organização da escola, concretamente efetivadas em seu interior, que têm papel importante com relação ao baixo rendimento do alunado, buscando identificar mecanismos poucos explícitos para a manutenção dessa situação.

Fruto de pesquisa financiada pelo CNPQ (Conselho Nacional de Desenvolvimento Científico e Tecnológico) desenvolvida nos anos de 2008 e 2009 em escolas públicas brasileiras, e prefaciado por Roberto Jamil Cury, o presente livro traz cinco estudos que tratam de temas de suma importância para a área da Educação, e sobretudo a Educação Especial, como a organização escolar, o gestor dirigente, a avaliação docente sobre o aluno e do aluno sobre o aluno, numa tentativa de identificar mecanismos que colaboram para a manutenção de uma inclusão excludente, no ambiente escolar.

Quais são as formas de organização da escola que, sem plena consciência dos educadores, estão contribuindo para criar contingentes de alunos excluídos das condições de acesso aos saberes, mas mantidos nas escolas? Buscando respostas para essa questão de pesquisa e com foco nas facetas da organização escolar, com destaque para a organização do trabalho educativo e a exclusão escolar, no estudo um, intitulado "Facetas de formas de organiza-

\footnotetext{
* Professora doutora pela UNESP. Pós- doutoranda pelo Departamento de Psicologia da UFSCar e Integrante do Grupo de Pesquisa LEPEDE'ES (Laboratório de Estudos e Pesquisa em direito à Educação - Educação Especial (UFSCAR). Araraquara, São Paulo.
} 
ção escolar e presença da exclusão na escola", Alda Junqueira Marin e Helena Machado de Paula Albuquerque, organizam os diversos focos da organização escolar ao redor de três blocos, a saber: a organização da escola; a organização do trabalho educativo; e por fim, as dinâmicas de gestão. Apontam que via estudos críticos, sabemos que a escola trabalha com a lógica excludente mostrando-se indiferente às diferenças e buscando homogenizar seu atendimento pedagógico, mas, como afirmam as autoras há tentativas de não ser indiferente as diferenças, mas que produzem efeitos tão ou mais maléficos, pois não só marcam subjetivamente os alunos como os segregam cultural e fisicamente em salas e turmas diferenciadas. Nesse ínterim, somos levados pelas autoras a confirmam, a hipótese de que por um lado a organização da escola segue seu ritual de obediência à legislação é à cultura, e por outro, inova para manter duplamente a diversidade desigual.

No estudo dois, denominado "O diretor frente ao processo de exclusão escolar", Helena Machado de Paula Albuquerque e Tathyana Gouvêa da Silva, buscam compreender a escola enquanto burocracia e expandir a análise para aquilo em que a instituição se diferencia desse modelo, revelando sua complexidade. Focalizam o diretor, trazendo os dados de uma das escolas, descrevem, analisam e buscam compreender a relação que os diretores estabelecem com a organização escolar, os impactos de suas ações, como eram percebidas e incorporadas pela escola e o que esta demandava para os diretores. No decorrer do trabalho, as autoras revelam a forte relação entre as ações diretivas e a organização escolar, bem como, alguns mecanismos dissimulados de exclusão no interior da escola, diretamente relacionados com a gestão escolar.

A manutenção da reprovação entre alunos e o abandono da escola em todas as séries iniciais do ensino, são ainda, problemas na escola pública brasileira, sendo que há um grande contingente que não consegue sobreviver às situações a que são expostos no interior da escola. Este é um dos resultados do estudo três, de Alda Junqueira Marin e Natalia Bonfim Nascimento, intitulado "Ações escolares em tempos de escolas cicladas". Com a finalidade de identificar alterações do rendimento das escolas quando se compara a organização seriada e ciclada, após as novas diretrizes de 1996 do país, procuram detectar as ocorrências de ações internas nas escolas de modo a compreendermos, ainda que parcialmente, os mecanismos que ainda oportunizam a existência de exclusão nas escolas, apesar das tentativas de elucidação e análises da realidade acompanhadas de implantação de medidas variadas.

No texto de José Geraldo da Silveira Bueno e Carlos Antônio Giovinazzo Júnior, que compõe o estudo quatro, "A relação entre práticas pedagógicas e o baixo rendimento", os autores têm como foco o juízo que os professores fazem sobre os alunos que parecem não corresponder às expectativas da escola, quer em relação ao rendimento acadêmico, quer aos aspectos comportamentais, mas que acabam implicando na avaliação negativa a respeito da apropriação de padrões exigidos pela escola. Apontam que parece prevalecer o fato de que as 
professoras ainda permanecem presas a padrões cristalizados, por exemplo, de avaliação, pouco condizentes com o alunado que hoje tem acesso à escola pública brasileira. Tendem a relacionar o baixo rendimento à própria organização da família e não na forma de organização da escola e da prática docente, imputando um tipo de julgamento que implica a incorporação, por parte dos alunos e de suas famílias, de que o problema de pouca aprendizagem reside neles e de que a escola cumpre seu papel.

Para finalizar, no estudo cinco, denominado "As relações sociais entre alunos com baixo rendimento escolar e seus pares", José Geraldo da Silveira Bueno e José Luiz Germano Martins, analisam as relações sociais estabelecidas entre alunos do ensino fundamental, com foco nos que são designados pela escola como os que possuem baixo rendimento escolar. Investigando todos os ambientes escolares, os autores realizam uma tentativa de se averiguar os critérios e aspectos que são privilegiados por esses alunos para o estabelecimento das relações sociais nos diferentes espaços e atividades desenvolvidas no interior da escola.

As discussões levantadas pelos autores proporcionam ao leitor, uma visão crítica das discussões que têm sido efetivadas na área, bem como permite realizar uma reflexão aprofundada sobre a exclusão na escola pública brasileira. Como ressalta Carlos Roberto Jamil Cury, o presente livro aponta para olhares que insistem em captar uma escola que persevera em um modo de ser e ao mesmo tempo deixa de atender a efetivação de uma escola democrática. Como em suas palavras, o livro aponta para uma situação ao mesmo tempo realista e insuportável, no âmbito da Educação, em que a escola acaba excluindo sem saber.

\section{Correspondência}

Rosimeire Maria Orlando Zeppone - Av. Prof. Eugênio Francisco Malaman, 674, Araraquara - São Paulo, CEP 14802-080.

E-mail: mzeppone@gmail.com 